should give a description of hermes on one page and then on the next describe Del Sud, which answers the description perfectly and comes from the type locality.

382. Lyccena melimono, Wright, = Ly. emigdionis, Grinnell, dimorphic $9 .-$ The two females $\mathrm{b}$ and c of Ly. Shasta also belong to emigdionis. As I have already pointed out (Ent. News, XVIII, p. 300), there is no of, Mr. Grinnell may have described it in error.

400. Ly. sissona, Wright.-A small species from Shasta County.

40I. Ly. astragala, Wright.-Another tiny species, the type (a of) is unique.

\title{
HESPERIDÆ.
}

423. Pamphila Californica, Wright.-Found in Southern California. 44 I. P. chispa, Wright, $=P$. Tecumseh, Grinnell.

480. Nisioniades lacustra, Wright.-A synonym of $N$. callidus, Grinnell.

\section{ANOTHER CHALCIDOID PARASITE OF A TICK.}

BY L. O. HOWARD, WASHINGTON, D. C.

It will be remembered that in Entomological News for November, I 907 (pp. 375-378, fig. I, plate XIV), the writer announced the unique breeding of a Chalcidoid parasite of the Ixodid, Hamaphysalis leporispalustris, collected by Mr. J. D. Mitchell, of Victoria, Texas, on a cotton-tail rabbit in Jackson County, Texas, and that the genus Ixodiphagus was erected for this species, which was called I. Texanus. It is now his pleasure to announce that another Chalcidoid has been reared from an Ixodid under conditions that leave no doubt as to the parasitic relation already so well established in the case of Ixodiphagts.

April 20, 1908, Mr. H. P. Wood collected numerous specimens of a brown tick from a smali Mexican dog at Corpus Christi, and sent them to the Dallas Laboratory of the Bureau of Entomology. This tick proved to be Rhipicephalus Texamus, Banks, recently described in Mr. Banks's Revision of the Ixodoidea, or Ticks, of the United States, Technical Series No. I 5, Bureau of Entomology of the U. S. Department of Agriculture, issued June 6, I908. The ticks were placed in charge of Mr. W. A. Hooker, of the Dallas Laboratory, who informs the writer that among them there were thirteen engorged nymphs and several slightly engorged adults. Mr. Hooker further states that the adults were placed in tubes July, 1908 
and the nymphs in a pill-box, all on moist sand. On May 4th, when examined, the nymphs appeared unusually swollen, so that parasitism was suspected, and they were immediately isolated in small tubes with absorbent cotton stoppers. The posterior portion of

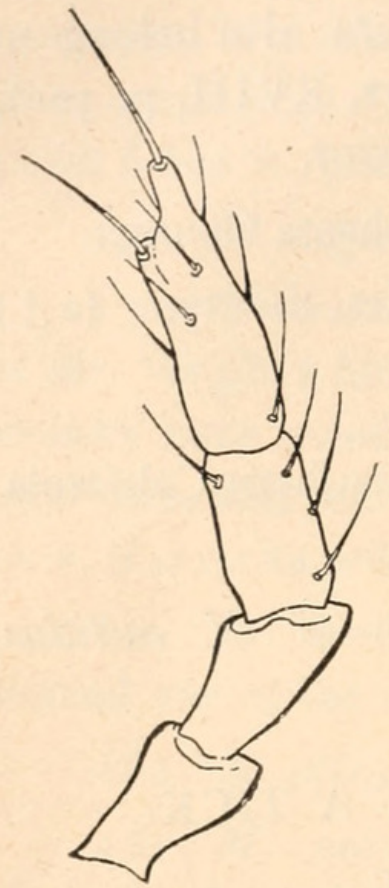

Fig I4.-Hunterellus Hookeri, female - maxillary palpus. the body of the host soon became translucent, indicating that parasite larvæ were at that end of the body. The first adult parasites appeared May 22, and $5 \mathrm{I}$ specimens issued from five ticks on the $22 \mathrm{nd}$ and 23 rd.

The full life-history of the parasite is not known, and the time and method of oviposition would be very interesting if they were known. It seems that it is the habit of the host to drop off the animal to which it is attached and to pass both moults on the ground. This would afford a good opportunity for the parasite to deposit its eggs while the young nymph is awaiting a host animal. From the fact, however, that a number of parasites issue from a single tick, there is a possibility of a polyembryonic method of development, in which case it is iikely that the Chalcidid may lay its egg in the egg of the tick. The exact dates sent in by Mr. Hooker are as follows: April i6, approximately the date when the nymphs became attached to the dog; April 20 the engorged nymphs were collected; May I 2 parasites pupated; May 22 the parasites began to emerge. Parasites were bred only from nymphs, and not from larvæ or from adults.

The parasite appears to be rather closely related to Ixodiphagus, but will form a new genus. As pointed out in the article in Entomological News above referred to, Ixodiphagus belongs to the subfamily Encyrtinæ, but does not fit into any of its tribes. It will therefore be desirable to found a new tribe, Ixodiphagini, to include Ixodiphagus and the new genus Hunterellus, about to be described.

Family Encyrtide, Walker (1837).

Subfamily Encyrtine, How. (i886).

Tribe Ixodiphagini, How.

Hunterellus, gen. nov.

Female-Differs from Ixodiphagus in the following respects: Head triangular when seen from side; antennæ inserted well above middle of 
face; face below insertion of antennæ well-rounded; distance between lateral ocelli and median ocellus greater than that between one of the laterals and the eye margin; maxillary palpi long; joints 2 and 3 subequal in length, and each as long as or longer than $\mathrm{I}$, joint 4 longer than 3 .

Male.-Resembles female except in antennæ, in which the funicle joints are all of equal width, each somewhat longer than broad, and all well separated, with rounded bases and sharply truncate tips; moderately hairy ; hairs not arranged in whorls.

Hunterellus Hookeri, n. sp.-Female.-Length, 0.85 mm.; expanse, $2.04 \mathrm{~mm}$.; greatest width of fore wing, $0.35 \mathrm{~mm}$. Head and mesonotum very finely shagreened, somewhat shining and furnished with many fine, short hairs. Mesopleura smooth, shining. General colour black. Antennæ dark fuscous. Front and middle tarsi and tibiæ dirty honeyyellow; hind tibiæ brownish in middle, honey-yellow at either end ; front and middle femora light at distal end. Veins of wing dark brown.

Male.-Resembles female except in antennæ, which are lighter in colour. Described from four females and six males, reared May 22 from Rhipicephalus Texanus collected on Mexican dog at Corpus Christi, April 20, 1908.

U. S. National Museum, type No. i I,947.

\section{PRELIMINARY REMARKS ON AMERICAN CORIZINI (HEMIPTERA).}

BY C. F. BAKER, PARA, BRAZIL.

In Uhler's check list there appeared eleven North American species of this group, all under the genus Corizus. But one of these (hyalinus) had also been found in Europe. Two were species of Dallas, one of Say, two of Stal, and the remainder date from the monograph of the genus by Signoret, published in 1859 in the Ann. Ent. Soc., France. The descriptions of Signoret are largely drawn from colour characters, and have consequently been the cause of endless confusion and misunderstanding in the determination of the species. The colour forms are simply multitudinous "protean," as stated by Distant. In large series from all parts of North, Central and South America specimens may easily be discovered that exactly fit the descriptions of Signoret, but they are mostly mere links in vast intergrading series of forms. In collections where these forms are July, 1908 


\section{$2 \mathrm{BHL}$ Biodiversity Heritage Library}

Howard, L. O. 1908. "Another chalcidoid parasite of a tick." The Canadian entomologist 40, 239-241. https://doi.org/10.4039/Ent40239-7.

View This Item Online: https://www.biodiversitylibrary.org/item/22229

DOI: https://doi.org/10.4039/Ent40239-7

Permalink: https://www.biodiversitylibrary.org/partpdf/14835

\section{Holding Institution}

MBLWHOI Library

\section{Sponsored by}

MBLWHOI Library

\section{Copyright \& Reuse}

Copyright Status: NOT_IN_COPYRIGHT

This document was created from content at the Biodiversity Heritage Library, the world's largest open access digital library for biodiversity literature and archives. Visit BHL at https://www.biodiversitylibrary.org. 